\title{
Police Use Of Excessive Force: A Case Study Of Lethal (Deadly) Force
}

\author{
Vedat Kargin, PhD \\ Turkish National Police
}

doi: 10.19044/esj.2016.v12n1p488 URL:http://dx.doi.org/10.19044/esj.2016.v12n1p488

\begin{abstract}
Two African-American civilians, Sean Bell and Amadou Bailo Diallo, suffered tragic deaths as a result of use of lethal force by the police. This case study presents an in-depth analysis of the determinants that affected the officers' use of lethal force with regard to the above mentioned cases.

In 1999, Amadou Bailo Diallo was killed in a 41-bullet police shooting in New York. Similarly in 2006, Sean Bell was shot to death in a 50-bullet fusillade that involved officers from The New York City Police Department. After the Bell shooting, officers of The New York City Police Department were under investigation. The case study focuses on and examines the similarities and differences of both cases, official and public reactions in the aftermath of the shootings, investigation processes, as well as the indictments of the police officers involved in both cases. Finally, this study proposes some suggestions on the use of excessive force based on the findings of the two specific cases.
\end{abstract}

Keywords: Police role, use of force, force continuum, "41 Shots," "50 shots.”

\section{Introduction}

In modern society, law enforcement agencies play a vital role. Law enforcement agencies provide the services for protection of the individual rights and freedoms, maintaining the public peace and order, ensuring the rule of law and preventing crime. A society without a strong law enforcement agency would eventually cease to exist. But, using of power and authority in a law enforcement agency always gives us a dilemma that is difficult to solve. On one hand, the law enforcement agency is given a breadth of responsibilities and the officers are entitled to use enormous power and authority over the citizens so that they can satisfactorily fulfill their duties and responsibilities. On the other hand, such use of powers and 
authority by the police significantly impacts the quality of life both in public and in private and sometimes may have devastating outcomes as in the cases of Bell and Diallo.

Being a law enforcement officer requires certain skills and special training. A part of this training is to be trained in the use of force to be able use force within numerous different circumstances. Cole and Smith point out that "the authority to use force is an inevitable and central part of police work" (1998) such a pivotal feature puts great pressure and responsibility on the shoulders of the law enforcement officers. As a matter of fact, majority of the police officers abide by the standards and do their jobs professionally. However, there is a small group of officers within the force who tend to abuse the power and authority given to them. That is why the actions of the police force are closely watched and followed both by media and the public.

In this crucial respect, it is the defining feature of the police role that differentiates the police from other public officials, such as teachers and doctors (Bittner, 1980). Yet, the capacity to use coercive force is one of the most problematic issues in policing due to the fuzziness in drawing a clear line between proper and improper use of force when necessary. In order to get the situation under control, police officers are authorized to use force on individuals who are behaving unlawfully. However, when using force an officer needs to maintain a balance. In a particular situation, if the amount of the force used by the officer exceeds the amount of force necessary to control the situation, then it is considered as police brutality. And, yet, inadequate use of force which is the amount of force less than necessary is considered as inefficiency (Worden, 1996). Contrastingly, in certain cases, police officers sometimes fail to apply the proper amount of force that is necessary to take the situation under control or some violence prone officers fail to cease it when the situation is under control. In each incident, the amount of force necessary, where and where it is necessary is a judgment call that requires great caution.

This section of the study provides an analysis of the underlying factors that caused the utilization of excessive force which resulted in fatal shootings of both individuals. Analysis takes certain factors such as, the similarities and the differences of both cases, official and public reactions aftermath the events and the processes of the investigations, as well as indictments of the police officers involved in the cases into account. Moreover, this section gives an overview of the existing literature to be able to draw conclusions and make suggestions at the end of the study.

\section{METHOD}

This study utilizes the case study research design because it is the best suited strategy to explore the nature of the police use of lethal force 
incidents. The behavior of an individual and of a group of individuals, as well as an issue that has been studied over time, can be examined by this research design strategy. Yin (2004), one of the most prominent writers on the case study research design, provides a complete explanation of the design when he states, "case study is an empirical inquiry that investigates a contemporary phenomenon within its real-life context, especially when the boundaries between phenomenon and context are not clearly defined.” (p. 13).

When doing research about the use of lethal force, it is extremely difficult to collect and find data that is relevant to the incidences in which the officers exceed their authority and resort to use of such force. Not being able to examine cases in real-life context is a major setback for the research in the field. This case study method will be the means to analyze two cases in reallife context, which is the unique feature of this study.

Similarly, to Thomas, "case studies are the analyses of persons, events, decisions, periods, projects, policies, institutions, or other systems that are studied holistically by one or more method. The case that is the subject of the inquiry will be an instance of a class of phenomena that provides an analytical frame -an object- within which the study is conducted and which the case illuminates and explicates" (2011, p. 511-521). As stated by Thomas, thanks to the case study research design, the characteristics of the officers involved in Bell and Diallo cases, the investigation processes, and court rulings will all be thoroughly examined.

Despite the fact that law enforcement agencies collect vast amount of data on crime, comprehensive, dependable, nationwide data on the prevalence and frequency of police use of lethal force is non-existent. Besides, existing studies on the subject leave out detailed information pertaining to circumstances under which lethal force is used by the officers. The author of this study believes that different sources of evidence, such as documents, archival records, interviews, and direct observation can play an important role in gaining a new perspective. Therefore, in this study two cases of police use of deadly force based on the archival records and documents are employed in order to obtain thick and detailed information about the issue. This strategy will enable us to have a better understanding of the nature of the use of deadly force by police. To sum up, the case study research design is a comprehensive research strategy that allows the researcher of this study to rely on the two cases of use of deadly force by police and to explore the phenomena in a holistic way.

\section{Literature Review}

Use of force is not a stable, one time incident but it rather is a process. Force may include physical force, lethal use of force, and the power 
to deprive people of their liberty through arrest (Bittner, 1980). In police training, officers are taught to make quick decisions whether to use force and the amount of force necessary to get the noncomplying person under control. The goal is to bring the resistive person into compliance. Officers are expected to evaluate the circumstances within the encounter and apply the proper amount of force without causing bodily injury. Use of force must immediately cease when the situation gets under control.

The use of force begins with the presence of police in the situation and may gradually heighten by the application of physical techniques, chemical weapons, and firearm. There is a shared structure named force continuum. Skolnik and Fyfe (1993) explain the force continuum process in seven stages; 1- Mere presence, 2- Verbalization, 3- Command voice, 4Firm grips, 5- Pain compliance, 6- Impact techniques, 7- Deadly force. Deadly force is the final step that can be used by police under certain circumstances, such as self-defense. This continuum of force is considered to be the measuring standard in many research studies that deal with the use of deadly force. The force continuum is a guideline, which is used by law enforcement officers to apply appropriate force to get the individuals to obey the laws or regulations. The continuum refers to escalating the force utilized over noncompliant individuals and to de-escalate the force in the situations with compliant individuals (McLaughlin, 1992, p. 65). However, sometimes officers can't apply the techniques properly or some violence prone officers initially may not cease the force hence might cause serious bodily injury or even death.

There is no agreed upon definition on the excessive use of force among academicians and practitioners. However, use of excessive force is generally recognized as the force above the justifiable amount of force when administrative guidelines, professional guidelines and legal standards are applied. Walker (Walker et al, 2004) emphasizes the importance of separating force and excessive force. He defines excessive force as any bodily force which is more than rationally needed to achieve a legal police purpose (p. 106). Similarly, McLaughlin (1992) identifies the excessive force as surpassing the limits of reasonable force. The courts describe reasonable force as the amount of force it takes to make it possible for the law enforcement officer to rationally affect the arrest and conquer the resistance. Therefore, excessive force is the amount of force used by police officers beyond the defined reasonable force limits.

Based on conflict perspective, theory of norm resistance proposed by Turk (1969) can be utilized to have a better understanding of the police use of excessive force during the encounters with the civilians. The theory explains how the different probabilities of conflict occur in authority-suspect encounters. According to the theory, there is a greater chance of conflict 
when citizens have strong social support and there is a less chance of conflict when both parties act more mature.

Similarly, Tedeschi and Felson's (1994) social interaction theory explains the situational factors, social exchange, and interplay between the actors within a given encounter. In this context, McCluskey, Terrill and Paoline (2005) examined how officers exercise coercive power in day-to-day encounters with citizens. They provide a good synopsis of three perspectives that explain police coercion in a tripartite framework; individual factors, organizational factors, and situational factors. On the other hand, none of these suggested factors by itself is sufficient to satisfactorily explain the problem of using excessive force but rather a combination of all factors are preferred when proving analysis of such cases.

The review of the literature indicates that various individual and social factors are related to use of lethal force. Such factors mainly consist of personal characteristics of the officers such as race, age, and gender. Professional qualifications include education, training, and work experience. Other factors are citizen/offender characteristics, type of police organization (traditional vs. professional), and situational characteristics such as social structure and public attitude towards the police.

The review also points out that most of the factors used to predict the use of force by officers seem to have a mixed relationship with use of force. Force, rage, age and gender are among the factors which are suggested to have relationship with the use of excessive force and have been the most scrutinized. Geller and Karales (1981) examined the relationship between the race of the officers and the shooting victims and concluded that black officers were more likely to have higher shooting rates than white officers. The difference can be attributed to the overrepresentation of black officers in off-duty shootings. Since black officers are more likely to reside in high crime neighborhoods, they are more likely to be involved in off-duty shootings. When the assignments and residence of the officers are controlled, no significant relationship between officers' race and on-duty shooting incidents is observed.

Blumberg (1997) in his study found that age of the officer and the length of service are strongly related to use of deadly force. Younger officers and officers with fewer years of experience are more likely to become involved in the use of deadly force and shooting incidents. In addition, Garner et al. (1996) studied 1,585 adult custody arrest situations in Phoenix, Arizona, and reported that the race of the suspect and the race of the officer were not predictive of use of excessive force. However, they found that incidents involving male police officers and male suspects were more likely to involve force. 
On the other hand, Sherman and Blumberg (1981) examined the link between the officers' education level and use of lethal force. The researchers found little relationship between these variables. Alpert and Dunham (1999) collected use of force data from three law enforcement agencies; police departments in two Oregon cities (Eugene and Springfield) and one county department in Florida (Miami Dade Police Department). The findings showed that there was no significant relationship between officer characteristics and the level of force used in different situations. As for the relationship between gender and force, there were no statistically significant differences between male and female officers. Furthermore, the ethnicity of the officer did not affect the general level of force used by the police. On the other hand, age was found to have a significant impact on force used by police in incidents. As the average age of the officer increases, the level of force used also increases. Sherman and Blumberg attribute this variance to the differences in assignments of younger versus older officers.

Another classification for the difference in the use of force by police is the type of organization. This can be seen in Wilson's (1968) typology of legalistic, watchman, and service type departments. In traditional police organizations, crime fighting is considered as the primary function of policing and coercion is an integral part of it. Pollock (2007) states this is because "criminals are seen as the "enemy" and fundamentally different from the "good" people. Police may use any means necessary to prevent crime, apprehend and punish the suspects. Officers perception of themselves as crime fighters may easily lead to use of excessive force decisions" (p. 190).

On the other hand, police departments adopting the public servant role of policing establish proactive partnership with citizens to identify and solve problems in the community. For example, community policing strategy is used to identify the risk factors of crime and find solutions before they turn to more serious problems. Officers participating in community policing projects exhibit less frustration and more positive attitudes toward the public than their non-community policing counterparts (Smith, 1994). At this type of police departments protection of citizens" fundamental rights and freedoms as well as the protection of the due process and the rule of law is accepted as equally important responsibilities of policing. Police perceiving their role as public servants view suspects and criminals like any other citizens who pay taxes, shop and live in society. At this type of police departments, officers have fewer citizen complaints regarding excessive use of force than officers working at traditional police departments (Pollock, 2007, p. 190).

Organizational culture or informal structure of police organization equally, maybe even more strongly, affects the conception of necessary and 
reasonable force. Police officers may feel that they are a part of a group that is isolated from the rest of the society. Peer group socialization and predisposition help officers forming their own standards of excessive force and developing excuses for their actions. The expectation of danger on the job may also have an impact on the attitudes of police officers towards the use of excessive force. Lester (1996) reports that police officers, by some measures, run a high risk of being injured or murdered on the job. The environment, neighborhood, and community characteristics where the police are assigned affect officers' perceptions of being at risk. Therefore, officers working in violent areas tend to use force more than necessary. Being in a community where the murder rate is high also affects officers' attitudes toward use of deadly force (Friedrich, 1980; Lester, 1996). The feeling of "expecting the unexpected" creates stress on police officers. That is, police officers are more likely use force when the suspect is antagonistic, agitated, or intoxicated; when the offense is a felony, or other citizens are present at the scene (Friedrich, 1980).

Another important component of the police-citizen encounter is the location of incident. Lundman (1994) examined public versus private places and found that more arrests were made in public places. The suspect's characteristics, particularly race of the suspect, also had an important role in police-citizen encounters. Alpert and Fridell (1992) note that relative to their representation in the whole population; the blacks disproportionately are the victims of police shootings. However, in his research in New York City, Fyfe (1988) reported that the subjects' race made little difference in the percentages of subjects wounded or killed among racial groups. Two of the most popular cases of police use of deadly force are discussed below within the context of the existing literature.

\section{Case\#1: “41 Shots”}

Incident: Amadou Diallo; a 23 year-old male, an African immigrant from Liberia, a street peddler, was shot and killed on February 4, 1999 in Bronx, NY after midnight by four plain clothed NYPD police officers from the Street Crime Unit. Diallo was unarmed at the time of the shooting; and had no police or court records. A total of 41 rounds were fired and 19 entered Diallo's body. The officers were in a patrol car searching for a serial rapist. All four officers got out of the car and approached Diallo. Diallo escaped to his apartment, officers broke into the apartment, and one of the officers shouted that Diallo put his hand into his jacket pocket and had a gun shaped something; in a matter of minutes Diallo was gunned down. However, the actual rape suspect was caught two months after Diallo was shot (Haberfeld, 2002). 
Officers' Characteristics: Officer McMellon, 27 years old, 5 years of experience, had numerous citizen complaints, fired 16 times. Officer Carroll, 36 years old, 6 years of experience, had numerous citizen complaints, fired 16 times. Officer Boss, 30 years old, 6 years of experience, had citizen complaints, fired 5 times. Officer Murphy, 5 years of experience, had no citizen complaints, fired 4 times (Cooper, 1999). To sum up, the characteristics of the officers involved in Diallo case are parallel to the characteristics identified to have links with the use of excessive force in the reviewed literature. Namely, all of the officers had short work experiences. Three of the officers had citizen complaints filed against them and were involved in shooting incidents before. All four officers were white males (Roane, 1999).

Investigation and criminal indictment: All four officers were charged with murder in the second degree (Haberfeld, 2002). All four refused to testify before the Bronx grand jury claiming that the members of the jury were under the influence of intense media coverage, anti-cop protests and demonstrations. As a result, the trial was moved to Albany where all four officers were acquitted from all criminal, federal and civil rights charges.

Response: Once the incident was heard by the public, public anger and indignation were heightened. Protests and demonstration organized by minority communities lasted for days condemning NYPD for the police brutality and racial profiling. Many people were arrested during the protests. Giuliani was the acting mayor of the city of New York. He defended NYPD providing statistics: NYC police officers fired 856 shots in 1998, down from 1,040 shots in 1997, and claiming New York City's police had a lower rate of shootings than had Washington, Boston, and Chicago police (Goodnough, 1999).

\section{Case \#2: “50 shots”}

Incident: Sean Bell, a 23 year old African American male was the second victim of police brutality and was killed in the early morning of the day of his wedding ceremony by five plain-clothed NYPD officers in November 2006 in Queens. Sean Bell was having his bachelor party at a night club notorious for prostitution and drug trafficking. The shooting took place when Bell was leaving the party with his two friends. He left the club and got in the car with his friends. The officers believed that Bell or his friends possessed guns. The officers approached the car, ordered the individuals to get out and to raise their hands. But the driver moved the car and hit an undercover officer and crashed into the police minivan. The officers fired their guns 50 times and Bell died at the hospital later that day.

Officers Characteristics: Of the five officers involved in the case, two were black, one was Hispanic, one was White, and one was Middle- 
Eastern male. Officers; Oliver, M. 35 years old white, fired 31 rounds, used two magazines; Isnora, G.F. 28 years old black, fired 11 rounds; Cooper, $\mathrm{M}$. 39 years old black, fired four rounds; Carey, M. fired three rounds; Headley, P. fired one round.

Investigation and criminal indictment: Officers Oliver, Isnora and Cooper were indicted, and the other two were not. On March 16, 2007, a Queens's grand jury charged two officers, Oliver and Isnora, with firstdegree and second-degree manslaughter, and Detective Cooper, with reckless endangerment. However, the case never became a racial issue because, in part, two of the three officers were black. All officers are cleared from all the charges on April 25, 2008. Officers will still face with civil case (Wilson, 2008).

Response: Public response was not much different from the responses given to Diallo case. Protests and demonstrations were held by community leaders. For the official response, however, the city officials appeared to be not covering or backing up the officers involved in the incident as opposed to what Mayor Giuliani did in Diallo case. In this case, Mayor Bloomberg met with the black community leaders and discussed the incident with them to make the community feel better and calm down. Bloomberg said "excessive force was used," and shooting was "unacceptable" (Cardwell and Chain, 2006).

\section{Implications and Conclusion}

Policing in racial and ethnic minority communities like New York is a very tough and sensitive function because it directly affects the public order and quality of life. Petrocelli et al. (2003, p. 4) in their study indicate that African-Americans constitute $25.6 \%$ of the overall population in New York City, but they comprised $50.6 \%$ of the people stopped by the NYPD officers. Hispanics were also stopped at higher rates than their presence in the overall population, whereas Whites were considerably underrepresented. The police-public contact survey conducted in 1999 by the Bureau of Justice Statistics demonstrated that African-Americans were more likely to be stopped by police officers than the others (Weitzer and Tuch, 2002, p. 436).

Any events of excessive use of force by police against minorities are largely publicized and condemned by the bulk of society. Both cases examined in this study occurred in New York City, which was a highly multiethnic and multiracial community. The New York City Police Department adopted zero-tolerance policing strategy in the 1990s, which was directed towards relatively minor quality-of-life issues, such as public urinating, spraying graffiti, and smashing a seat in the park. However, the zero tolerance policy is believed to encourage police abuse of citizens. And, in fact, complaints against New York City police officers increased in the 
1990s. From 1994 through 1996 the police department paid out over $\$ 70$ million for police misconduct (Bernard, 1998, 295; NIJ and BJS, 1999, p vii).

In the first case (41 Shots), since the officers were searching for a high profile criminal, the perception of conflict was very high and situational factors were also involved. Racial profiling allegations about police officers are not supported by the overall picture. In the first case, all officers are male and the both victims are African American. In the second case (50 shots), the race of the officers is mixed. Officers' ages are similar in both cases. Both cases occur after midnight. The factors that affect police discretion on use of force in both cases are parallel to the findings in the literature review.

Proposed early warning system can be one of the solutions to reduce the excessive use of force by police. The aim of the system is to identify individual officers showing signs of improper behavior and attitudes towards minority groups before they involve in the excessive use of force. The system also aims to provide officers who may be having problems on the job with the appropriate counseling and training (Walker, 2001).

Police departments should rely exclusively on pre-employment screening to identify violence-prone candidates during the recruitment process before joining the police force. Police departments may also utilize services of psychologists to identify violence-prone officers to predict future officer performances. Citizen complaints of excessive use of force may be used by police administrators to identify officers at risk for excessive force and refer them to police psychologists for counseling and further evaluation. Further research aiming to identify risk factors for negative police behaviors by analyzing individual officer characteristics, background information combined with their police academy records and in service records must be carried out. The findings of studies concentrated on excessive force can help police administrators identify the predictors of police misbehavior and prevent unnecessary use of force in the future.

On the other hand, the problem of excessive use of force by police may be resulting from organizational and departmental factors as well. The existing literature shows that excessive use of force by police stem not only from individual traits of the officers but also from organizational factors. In this respect, departmental factors should be examined cautiously. Any indications of prejudice towards minority groups and tolerance of excessive force at the departmental level among the officers must be treated by police administrators carefully. Cultural diversity training should be offered to police officers to increase their level of awareness of the existing cultural norms in the communities that they serve. The training may help officers handle and solve probable conflicts with citizens of different cultures during 
their daily routine activities and reduce the possibility of excessive use of force by police.

\section{References:}

Alpert, G.P., Dunham, R.G. (1999). “The Force Factor: Measuring and Assessing Police Use of Force and Suspect Resistance” in Use of Force by Police: Overview of National And Local Data. Washington D.C.: U.S. Department of Justice, National Institute of Justice and Bureau of Justice Statistics, October 1999.

Alpert, G. P., and Fridell, L. A. (1992). Police Vehicles and Firearms: Instruments of Deadly Force. Prospect Heights, IL: Waveland Press.

Bernard, H. (1998). Reflecting on the Subject: A Critique of the Social Influence Conception of Deterrence, the Broken Windows Theory, and Order Maintenance Policing New York Style. Michigan Law Review 97, 291-389.

Bittner, E. (1980). The Capacity to Use Force as the Core of the Police Role. In Bittner, The Functions of the Police in Modern Society, pp. 36-47.

Blumberg, M (1997). “Controlling Police Use of Deadly Force: Assessing Two Decades of Progress” in R. Dunham and G. Alpert (Eds.) Critical Issues in Policing. Prospect Heights, IL: Waveland Press.

Cardwell, D. and Chain, S. (2006, November 28). Mayor Calls 50 Shots by the Police 'Unacceptable.' The New York Times. Retrieved June 18, 2008 from http://www.nytimes.com/.

Cole, G. F. and Smith, E. C. (1998). The American System of Criminal Justice. Belmont, CA: Wadsworth Publishing Co.

Cooper, M. (1999, February 5). Officers in Bronx Fire 41 Shots, and an Unarmed Man Is Killed. The New York Times. Retrieved April, 20, 2007 from http://www.nytimes.com/.

Friedrich, R.J. (1980). Police Use of Force: Individuals, Situations, and Organizations. Annals of the American Academy of Political and Social Science, 452, 82-97

Fyfe, J. J. (1981). Who Shoots? A Look At Officer Race And Police Shooting. Journal of Police Science and Administration. 9 (4): 367-382

Fyfe, J. (1988). Police Use of Deadly Force: Research and Reform. Justice Quarterly, 5(2): 165-205

Garner, J., Buchanan, J., Schade, T., Hepburn, J. (1996). Understanding the Use of Force by and Against the Police. NIJ Research in Brief, November 1996.

Geller, W. A., \& Karales, K. J (1981). Split-Second Decisions: Shootings Of \& By Chicago Police. Chicago: Chicago Law Enforcement Study Group. 
Goodnough, A. (1999, February 11). Mayor Offers New Statistics In Defense Of the Police. The New York Times. Retrieved April, 10, 2007 from http://www.nytimes.com/

Haberfeld, R. M. (2002). Critical Issues in Police Training. Upper Saddle River, NJ: Prentice Hall.

Lester, D. (1996). “Officer Attitudes toward Police Use of Force” in William Geller and Hans Toch (Eds.) Police Violence: Understanding and Controlling Police Abuse of Force. Yale University Press.

Lundman, R.J. (1994). Demeanor or Crime? The Midwest City PoliceCitizen Encounters Study. Criminology. 32(4): 631-656.

McLaughlin, V. (1992). Police and the use of force: the Savannah study. Westport, Connecticut: Praeger.

National Institute of Justice (U.S.), \& United States. Bureau of Justice Statistics. (1999). Use of force by police [paper, electronic resource] : overview of national and local data. Washington, DC: U.S. Dept. of Justice, Office of Justice Programs, National Institute of Justice. Retrieved from http://www.ojp.usdoj.gov/bjs/abstract/ufbponld.htm.

Petrocelli, M., Piquero, A. R. \& Smith, M. R. (2003). Conflict theory and racial profiling: An empirical analysis of police traffic stop data. Journal of Criminal Justice, 31(1): 1-10.

Pollock, J. M. (2007). Ethical Dilemmas and Decisions In Criminal Justice. Belmont: Wadsworth.

Roane, R. K. (1999, February 5). Three of the Officers Were Involved in Shootings in the Last 2 Years. The New York Time. Retrieved April, 18, 2007 from http://www.nytimes.com/.

Sherman, L. W. and Blumberg, M. (1981). Higher Education and Police Use of Deadly Force. Journal of Criminal Justice. 9(4): 317-331

Smith, M.R. (1994). Integrating Community Policing and the Use of Force: Public Education, Involvement, and Accountability. American Journal of Police. 8(4): 1-21

Tedeschi, J. T., \& Felson, R.B. (1994). Violence, aggression, and coercive actions. Washington DC: American Psychological Association.

Turk, A. (1969). Criminality and Legal Order. Chicago: Rand McNally. McCluskey, J.D., Terrill, W. \& Paoline, III. E.A. (2005). Peer Group Aggressiveness and the Use of coercion in Police-Suspect Encounters. Police Practice and Research, 6(1): 19-37

Skolnick, J.H. \& Fyfe, J. (1993). Above the law: Police and excessive use of force. New York: The Free Press. 37-40.

Thomas, G. (2011). A typology for the case study in social science following a review of definition, discourse and structure. Qualitative Inquiry,17 (6): 511-521 
Walker, S. (2001). Police Accountability: The Role of Citizen Oversight. Belmont, CA: Wadsworth Thompson.

Walker, S., Spohn, C. \& DeLone, M. (2004). The color of justice: race, ethnicity, and crime in America (3rd ed.). Belmont, CA: Wadsworth/Thomson Learning.

Weitzer R. \& Tuch, S. A. (2002). Perceptions of racial profiling: race, class and personal experience, Criminology, 40(2): 435-456.

Wilson, J. Q. (1968). Varieties of police behavior: The management of law and order in eight communities. Cambridge, MA: Harvard University Press. Wilson, M. (2008, April 26). Judge Acquits Detectives in 50-Shot Killing of Bell. The New York Time. Retrieved June 18, 2008 from http://www.nytimes.com/.

Worden, Robert E., "The 'Causes' of Police Brutality: Theory and Evidence on Police Use of Force," in Police Violence: Understanding and Controlling Police Abuse of Force (1996). (Eds.) William A. Geller and Hans Toch. New Haven, CT:Yale University Press.

Yin, R. K. (2014). Case Study Research: Design and Methods. London: Sage Publications 